\title{
遠心圧縮機ディフューザに発生する前縁渦の非定常挙動と制御*
}

\author{
後藤 尚 志*1, 太田 有*1, 大田 英 輔*2

\section{Unsteady Behavior and Control of Diffuser Leading-Edge Vortex in a Centrifugal Compressor}

\author{
Takashi GOTO*3, Yutaka OHTA and Eisuke OUTA \\ ${ }^{* 3}$ Department of Applied Mechanics and Aerospace Engineering, Waseda University, \\ 3-4-1 Okubo, Shinjyuku-ku, Tokyo, 169-8555 Japan
}

\begin{abstract}
The unsteady behavior of a vortex generated on the diffuser leading-edge, which is called the leading-edge vortex (LEV), is discussed through experiments and numerical simulation. The LEV is different from the separating vortex of the diffuser leading-edge and passage vortex of the diffuser, develops rapidly with a decrease in the compressor mass flow rate, and forms a flow blockage in diffuser passages. Therefore, the evolution of the LEV may become a cause of diffuser stall. Additionally, in one attempt to control the LEV, two types of tapered diffuser vanes, which are shroud- or hub-side tapered diffuser vanes, were adopted. Though the shroud ${ }^{-}$side tapered diffuser vane can effectively reduce the compressor noise level, the compressor performance deteriorates remarkably. On the other hand, the hub-side tapered diffuser vane not only reduces the compressor noise level but also improves the compressor performance. According to the visualization results of the oil-film methods and numerical simulations, the hub-side tapered diffuser vane can suppress the evolution of the LEV in the compressor low-flow-rate operation.
\end{abstract}

Key Words : Turbomachinery, Centrifugal Compressor, Leading-Edge Vortex, Tapered Diffuser Vane, CFD, Noise

\section{1. 緒言}

遠心圧縮機をはじめとするターボ機械は省エネルギ の観点から高効率化が強く.要求されている。そのた め, ターボ機械のひとつである遠心圧縮機には高効率 化に向けて羽根付ディフューザが多く採用されてい る。しかし，ディフューザに案内羽根を設置すると高 効率が得られる反面, 羽根車吐出流が周期的に案内羽 根に衝突し, 著しく高いレベルの騒音が単一周波数で 発生するため, 聴覚的に非常に不快な騒音の原因とな る(1).このことから, 圧縮機周辺の作業環境の改善の 要求は高く，また環境問題に対する関心の高さも相ま って, 発生騒音低隇化法の確立や騒音発生機構の解明 が急務とされ，遠心圧縮機の低騒音化設計の指針を得 ることは必要不可久となっている.

そこで著者らは羽根付ディフューザを有する遠心圧 縮機汭いて支配的な発生騒音となる動静翼干渉騒音 に着目し, 圧縮機性能の改善および発生騒音の低滅化

\footnotetext{
* 原稿受付 2010 年 4 月 20 日

*1 正員, 早稲田大学理工学術院 (昰 169-8555 東京都新宿区大 久保 3-4-1).

*2 正員, フェロー, 早稲田大学.

E-mail:t.goto@aoni.waseda.jp
}

を同時に指向したディフューザ案内羽根の設計指針を 得ることを目的として研究を行っている. 従来の騒音 に関する研究は, Yoshinaga ら(1)による遠心圧縮機 から発生する騒音の検討，児玉ら(2)によるロブパター

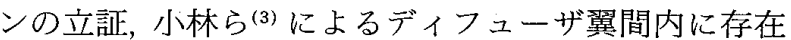
する定在波が特定の周波数において大きな騒音源にな ることの解明など多種多様に行われている。一方，圧 縮機性能に関する研究は, 運転範囲の拡大を目指した 報告として，西田ら ${ }^{(4)}$ や足立ら ${ }^{(5)}$ は，羽根なしディフ ューザの流路幅に絞りを入れ，サージマージンの改善 を試みている．また，高効率化を目指した研究では， 中川ら ${ }^{(6)}$ はディフューザ案内羽根流入部に小翼を設 置することにより剥離の抑制に成功している。しか し, 発生騒音の低減化には圧縮機性能の劣化, 圧縮機 性能の改善には発生騒音の音圧レベルの上昇が常に伴 って抢り,この両面を同時に扱った研究は, 速水ら(7) による小弦節比ディフューザの開発が報告されている もののほとんど例がないのが現状である。

従来の研究により著者ら ${ }^{(8) \sim(11)}$ は, ディフューザ案 内羽根前縁形状が発生騒音および圧縮機性能に大きな 影響を与えることを示し, 案内羽根前縁に 3 次元テー パ加工を施したテーパ形案内羽根を提案した。このテ 一パ形案内羽根は性能を維持しつつ発生騒音の主な成 
分である動静翼干渉騷音だけでなく広帯域騒音も同時 に低減することが可能である。また，遠心機特有の強 い3 次元性とスパン方向の非一様性によって案内羽根 前縁に発生する前縁渦の存在を明らかにし，この前縁 渦が圧縮機性能, 特に低流量運転状態における性能に 大きな影響を与えることを示した。

本研究では, 遠心圧縮機の案内羽根前縁の負圧面シ ュラウド側前縁に発生するディフューザ前縁渦(以下, 前縁渦と略記) の非定常挙動に焦点を当て, 実験およ び数值解析により調查を行った。また,テーパ形案内 羽根を適用することにより前縁渦の成長を抑制し，低 流量運転状態における圧縮機性能を改善することが可 能であることを示す。

\section{2. 記 号・単 位}

$B_{T}$ : 案内羽根前縁高さ $\mathrm{m}$

$B$ : 通路幅 $\mathrm{m}$

$D:$ 直径 $\mathrm{m}$

$L_{c}$ : 案内羽根翼弦長 $\mathrm{m}$

$L_{e}$ : 案内羽根前緑切り込み深さ $\mathrm{m}$

$L_{i d}$ : 動静翼間距離 $\mathrm{m}$

$N$ : 動翼回転数 $\mathrm{min}^{-1}$

$P$ : 静压 $\mathrm{Pa}$

$Q:$ 体積流量 $\mathrm{m}^{3} / \mathrm{s}$

$t:$ 時間 $\mathrm{s}$

$t_{b p}:$ 羽根車一翼間通過時間 $\mathrm{s}$

$t^{*}$ : 無次元時間 $=t / t_{b p}$

$\Delta t$ : 時間刻み $\mathrm{s}$

$u:$ 流速 $\mathrm{m} / \mathrm{s}$

$u_{t}$ : 羽根車出口周速 $\mathrm{m} / \mathrm{s}$

$v_{r}$ : 半径方向速度 $\mathrm{m} / \mathrm{s}$

$\phi:$ 流量係数 $=Q / \pi^{2} D_{2}^{2} B_{2} N$

$$
\begin{aligned}
\beta & : \text { 流入角 } \\
\beta_{b} & : \text { 入口角 } \\
i_{b} & : \text { 入射角 }=\beta-\beta_{b} \\
\psi & : \text { 圧力係数 }=2 P_{t} / \rho \pi^{2} D_{2}^{2} N^{2}
\end{aligned}
$$

添字

$$
\begin{aligned}
& 1: \text { 羽根車入口 } \\
& 2: \text { 羽根車出口 } \\
& 3: \text { 案内羽根入口 } \\
& 4: \text { 案内羽根出口 } \\
& p: \text { 圧力面 } \\
& s: \text { 負圧面 }
\end{aligned}
$$

\section{3. 実験装置および方法}

$3 \cdot 1$ 実験装置概要 供試圧縮機は舶用ディーゼ ルエンジンに用いられる過給機用遠心圧縮機である。 図 1 に供試圧縮機の概略を示す，本来供試圧縮機の定 格回転数は $22000 \mathrm{~min}^{-1}$ であるが，著者らのこれまで の研究により, 本報で着目する前縁渦は亜音速から遷 音速までの広い運転状態において発生することがわか っている.そこで, 本報では前縁渦の挙動調査の第一 段階として，回転数を $6000 \mathrm{~min}^{-1}$ として実験および 数值解析を実施した。これは衝撃波や強い二次流れの 影響を除外し, 前縁渦の挙動に焦点をあてた検討をす ることに相当する.

供試圧縮機は騒音計測のため無響室に設置されてお り，暗騒音は圧縮機の騒音レベルに比べて十分に低い レベルである.

供試圧縮機に用いた羽根車とディフューザの仕様を 表 1 に示す。供試羽根車は開放形羽根車であり, 翼枚 数はインデューサを備えた長羽根 7 枚と短羽根 7 枚の 計 14 枚となっている. 実験には, 羽根なしディフュ ーザと 15 枚の案内羽根を有する羽根付ディフューザ

Revolution Measurement System

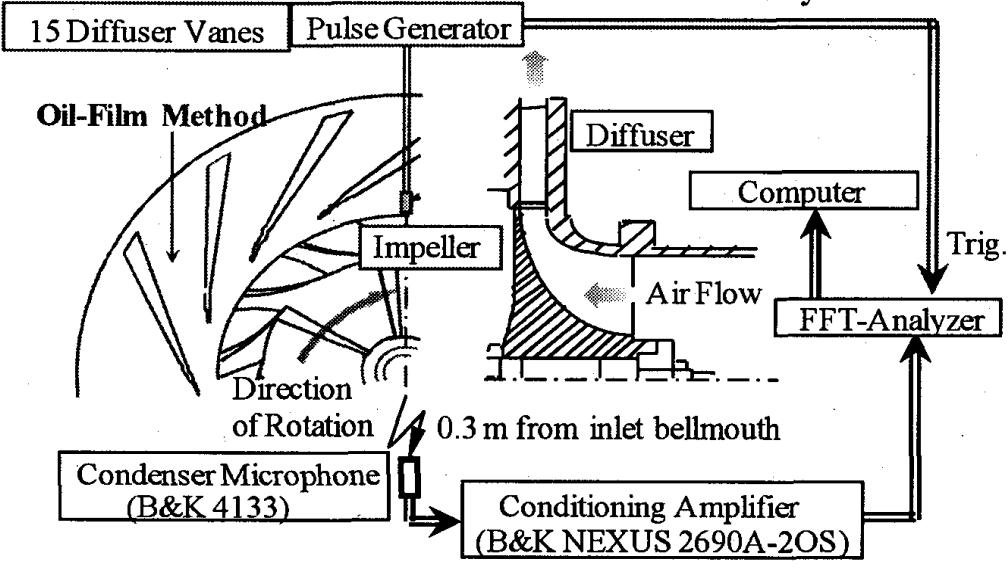

Noise Measurement System

Fig. 1 Experimental apparatus and measuring system 
Table 1 Dimensions of tested compressor

\begin{tabular}{ll|ll}
\hline \multicolumn{4}{c}{ Tested Centrifugal Compressor } \\
\hline Rotational Speed & $N$ & 6000 & $\mathrm{~min}^{-1}$ \\
Mass Flow Rate & $G$ & 1.64 & $\mathrm{~kg} / \mathrm{s}$ \\
Pressure Ratio & $P_{5} / P_{0}$ & 1.1 & \\
\hline \multicolumn{4}{c}{ Impeller } \\
\hline Number of Blades & $Z$ & 14 & \\
$\quad$ (Main + Splitter) & & \multicolumn{2}{c}{$(7+7)$} \\
Inlet Diameter & $D_{1}$ & 248 & $\mathrm{~mm}$ \\
Outlet Diameter & $D_{2}$ & 328 & $\mathrm{~mm}$ \\
Exit Blade Width & $B_{2}$ & 26.14 & $\mathrm{~mm}$ \\
\hline \hline \multicolumn{4}{c}{ Diffuser } \\
\hline Blade Shape & $V$ & Wedge \\
Number of Vanes & $V$ & 15 & \\
Leading Edge Diameter & $D_{3}$ & 360 & $\mathrm{~mm}$ \\
Trailing Edge Diameter & $D_{4}$ & 559 & $\mathrm{~mm}$ \\
Diffuser Width & $B_{4}$ & 26.14 & $\mathrm{~mm}$ \\
\hline
\end{tabular}

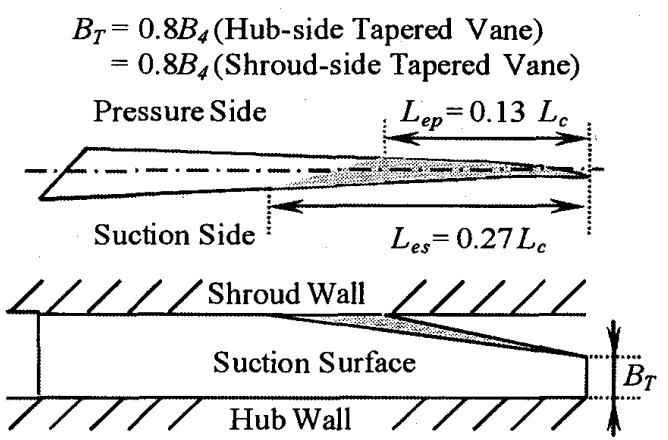

(i) Shroud-side tapered vane

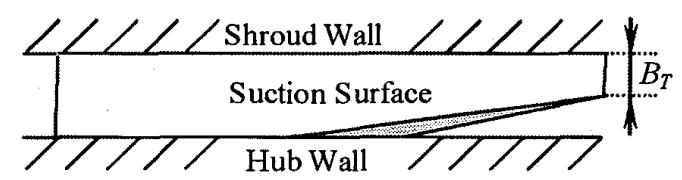

(ii) Hub-side tapered vane

Fig. 2 Geometries of modified tapered diffuser vane

の 2 種類を採用した。羽根付ディフューザの動静翼間 距離 $L_{i d}$ は $16 \mathrm{~mm}$ とした。

本研究では, 通常用いられるくさび型案内羽根と 2 種類のテーパ形案内羽根の計 3 種類を自主製作して実 験を行った。

$3 \cdot 2$ テーパ形案内羽根仕様 テーパ形案内羽根 とは図 2 に示すように案内羽根前縁に 3 次元のテーパ 加工を施した案内羽根である。この加工により羽根車 吐出流と案内羽根との干涉面積を縮小し, 動静翼干渉 騒音の騒音レベルの低減を指向した設計がなされてい る. 実験では，八ブ側のみにテーパ加工を施された八 ブ側テーパ形案内羽根 (以降, HTV)，シュラウド側 のみにテーパ加工を施されたシュラウド側テーパ形案 内羽根(以降, STV)の 2 種類を用いた。テーパ部の
加工切り込み深さは圧力面側 $L_{e p}$ と負圧面側 $L_{e s}$ で それぞれ翼弦長 $L_{c}$ の $13 \%$ 抢よび $27 \%$ とした。また， 案内羽根前緑高さ $B_{T}$ はディフューザ通路幅に対して $90 \%$ から $20 \%$ まで $10 \%$ 毎に変化させた。

$3 \cdot 3$ 測定方法計測システムを図 1 に示す。圧 縮機の動作点は吐出管後方に設置したバタフライ弁に より調節した。また，圧縮機流量扔よび圧力上昇は， それぞれ吐出管路に設置されたオリフィスおよび差圧 発信器により計測した。発生騷音は吸込管ベルマウス 軸線上 $0.3 \mathrm{~m}$ 離れた地点に設置したコンデンサマイ クロフォン (B＆ K 社 4133)により計測し, 得られた 信号をコンディショニングアンプ(B＆ K 社 NEXUS 2690A)により増幅し, $\mathrm{A} / \mathrm{D}$ 変換した後周波数解析 (小 野測器 DS-2000)を行った.

実験装置扔よび測定系の詳細は関連報告(8) (11) を参 照されたい。

\section{4. 数 値 解 析 法}

$4 \cdot 1$ 解析スキーム テーパ形案内羽根が内部流 れ場に与える影響, 前縁渦の生成メカニズムおよびそ の非定常挙動を解明するために数值解析を実施した。 支配方程式は連続の式, 3 次元圧縮性 Navier-Stokes 方程式, エネルギ保存の式および理想気体の状態方程 式であり，有限体積法により離散化した。対流項には Weight Compact Nonlinear Scheme (WCNS) ${ }^{(12)} に$ より高次精度化した Flux Difference Splitting (FDS) ${ }^{(13)}$ を用い, 粘性項はガウスの定理に基づく 2 次精度中心差分より評価した。また，時間積分には LU-SGS 陰解法 ${ }^{(14)}$ を採用した。乱流モデルには Spalartら(15)により提案されたLES/RANS ハイブ リッドモデルである Detached Eddy Simulation を採 用した。本研究では, LESとして Smagorinsky モデ ルを適用し， RANS として Spalart-Allmaras モデル を用いた。相対系(非慣性系)には慣性力として遠心力 およびコリオリカを考慮した。

$4 \cdot 2$ 解析格子 数值解析に用いたメッシュを図 3 亿示す。羽根車内部㧤よびディフューザ内部の翼間 は $\mathrm{H}$ 型の構造格子により生成した。計算領域は, 相 対系(非慣性系)として扱う羽根車領域, 羽根車チップ クリアランス領域および絶対系(慣性系)として扱うデ イフューザ領域，テーパ部領域の 4 領域に分割した. また, チップクリアランス領域扮よびテーパ部領域は 重合格子として解析格子に組み込んだ。

本数值解析では, 前緑渦の非定常挙動を調查する第 1 段階として, 短羽根を間に 1 翼含む羽根車 1 長翼間 と案内羽根 2 翼間を計算領域とした。ただし，対象と 
した遠心圧縮機は羽根車翼枚数および案内羽根翼枚数 が互いに素(それぞれ，14 枚，15枚)であるため，本数 値解析では，案内羽根翼枚数を 14 枚であるとして解 析格子を調整した。

格子点数はチップクリアランスを含む羽根車領域は 約 2727000 点, ディフューザ部は約 2746000 点とな っており，総格子点数は 5473000 点である.また, テ 一パ形案内羽根設置時にはテーパ部に1 248000 点の 格子を設置した。

$4 \cdot 3$ 設定条件および境界条件 数值解析では, 羽根車回転数は実験と同様の $6000 \mathrm{~min}^{-1}$ とした。ま た時間刻みを $\Delta t=5 \times 10^{-4} t_{b p}$ とし，数值的な振動が収

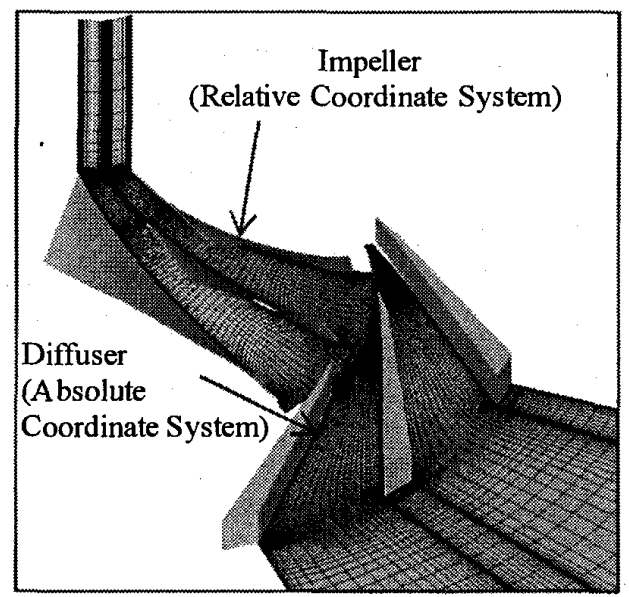

Fig. 3 Overview of computational domain
束した時刻を基準時間 $t=0$ として, 無次元時間 $t^{*}=$ $t / t_{b p}=10$ になるまで解析を行った。大気条件は標準 圧力および標準温度とした，入口境界には等エントロ ピ流れを仮定し，全温および全圧を一定とした。また， 一次元無反射条件を適用した。さらに出口境界には， 絞り抵抗モデルを導入して出口境界の圧力と出口境界 を通る流速とに関連性を与えた。また，羽根車領域と ディフューザ領域の接合面はスライディング補間によ り保存量の補間を行った。周方向境界には周期境界を 適用した，重合領域には重合格子法により補間を行っ た。その他の壁面には断熱壁を仮定し，粘着条件を課 した。

\section{5. 結果および考察}

$5 \cdot 1$ 圧縮機特性圧縮機性能および騒音特性を 図 4 の左図に示す. 左上図, 左下図はそれぞれ流量係 数 $\phi$ に対する圧力係数 $\phi$ および騒音レベルを表示し ている.また流量係数 $\phi=0.24$ の騒音スペクトルを 図 5 に示す.図 4 における $\phi=0.24$ は $6000 \mathrm{~min}^{-1}$ 運 転時における供試圧縮機の最高効率点であり， $\phi=$ 0.18 はくさび型案内羽根を有する羽根付ディフュー ザを採用した供試圧縮機の吐出し静圧の勾配が負と転 じる点である.

図 4 左上図の圧縮機性能より，くさび型案内羽根 (15 VD) をディフューザに設置すると羽根なしディフ ューザ(VL) 設置時に比べ高い圧力上昇が得られるこ

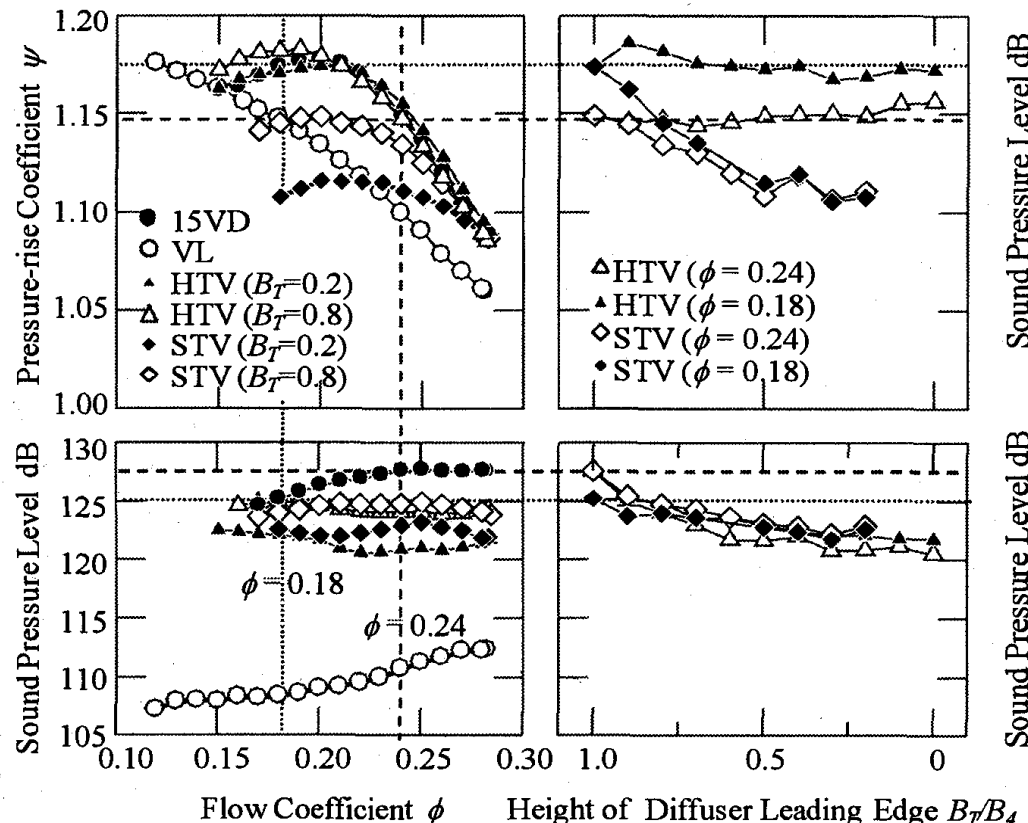

Fig. 4 Compressor performance and characteristics of radiated noise $\left(N=6000 \mathrm{~min}^{-1}\right)$
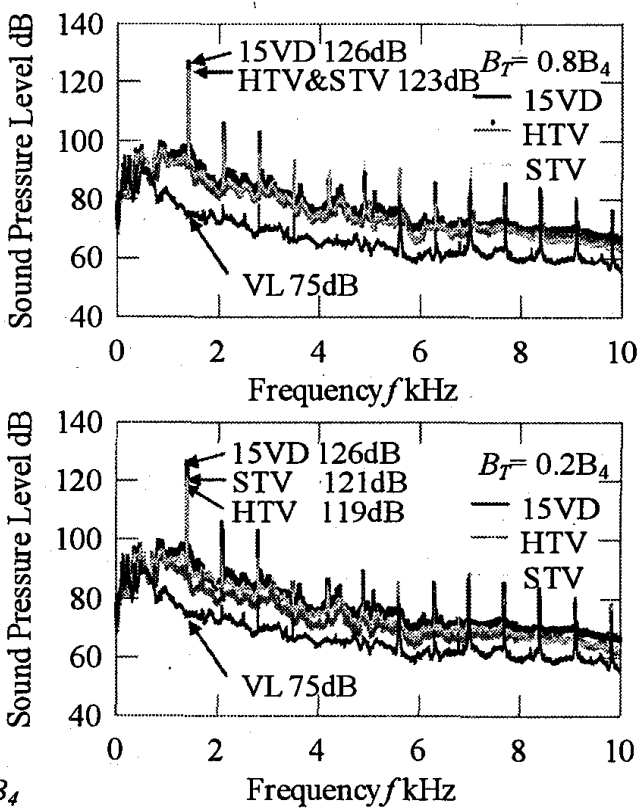

Fig. 5 Typical power spectra of compressor noise with vaned diffuser $(N=6000$ $\min ^{-1}, \phi=0.24$ ) 
とがわかる.しかし，VL設置時に比べ，右上がり不 安定領域の拡大と共に, 発生騒音レベルが図 4 (左下) に示されるように $20 \mathrm{~dB}$ 以上上昇している。この発 生騒音レベル上昇の原因は, 図 5 に示す騷音スペクト ルから広い周波数帯にわたって広带域騒音レベルが上 昇するのに加え, 離散周波数騒音が著しく上昇するた めである. 特に, 動静翼干渉騒音の基本周波数(1.4 $\mathrm{kHz})$ の騒音レベルは $40 \mathrm{~dB}$ 以上上昇する。これは, 羽根車吐出流と案内羽根の前縁部が直接干渉するため であり, 案内羽根前緑形状は発生騒音低減の一つの重 要なパラメータである.

図 4 の左下図よりテーパ加工を施すことで羽根吐出 流との干涉面積が小さくなるように設計された HTV およびSTVを用いると, 発生騒音を効果的に低減可 能であることがわかる。また図 5 の騒音スペクトルか ら, テーパ形案内羽根は動静翼干涉騒音だけでなく, 広带域騒音をも低減可能であることがわかる．しか し, STVを用いると図4 の左上図に示される通り全 運転範囲において性能は劣化する.この要因について は油膜法の結果とともに5・2 節で述べる. 一方, HTV は全運転範囲において高い圧力上昇を維持する ことが可能である.さらに, 低流量運転状態において, 安定作動範囲の拡大も可能となる.この要因について も $5 \cdot 2$ 節にて油膜法の結果とともに述べる.
次に,テーパ形案内羽根の前縁高さ $B_{T}$ が性能抢よ び騒音レベルに与える影響を実験により調査した。図 4 の右図に HTV および STV の前縁高さ $B_{r}$ に対す る性能(上図)および騒音レベル(下図)を示す。前縁高 さ $B_{T}$ は $0.9 B_{4}$ から $0.2 B_{4}$ まで変化させた。なお, $1.0 B_{4}$ はくさび型案内羽根を意味している. また, 点 線および破線は $\phi=0.24$ および 0.18 におけるくさひ 型案内羽根 $\left(B_{T}=1.0 B_{4}\right)$ の性能抢よび騒音レベルを 示している.

図 4 の右下図より STVでは, 前縁高さ $B_{T}$ が減少 するにつれて, 騒音レベルは減少するものの, 性能(図 4 の右上図) も同時に劣化する傾向があることがわか る. 一方 HTVでは, 案内羽根前縁高さ $B_{T}$ を変化さ せても， $\phi=0.24$ おび 0.18 のどちらにおいても， $\mathrm{STV}$ と異なり大きな劣化は確認されない. 特に案内 羽根前縁高さ $B_{T}=0.18 B_{4}$ では, 性能を改善しつつ, 安定作動範囲を拡大することが可能であった。また前 縁高さ $B_{T}=0.2 B_{4}$ では, 性能を維持したまま, 発生騒 音を設計運転点において $3 \mathrm{~dB}$ 低減することが可能で あった。

$5 \cdot 2$ 案内羽根翼間における内部流れ場 くさび 型案内羽根を設置した際のディフューザシュラウド壁 の油膜法による可視化結果を図 6 に示す. 左図は $\phi=$ 0.24 , 右図は $\phi=0.18$ における可視化結果である. 図

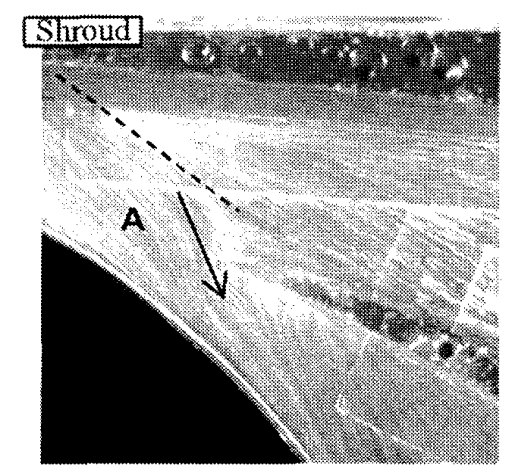

(i) Shroud wall near leading edge $(\phi=0.24)$

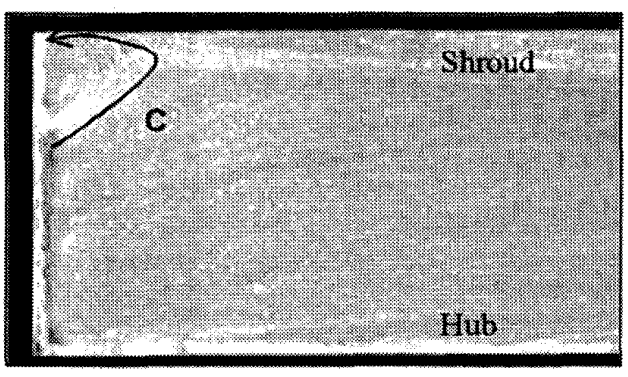

(ii) Suction surface near leading edge $(\phi=0.24)$

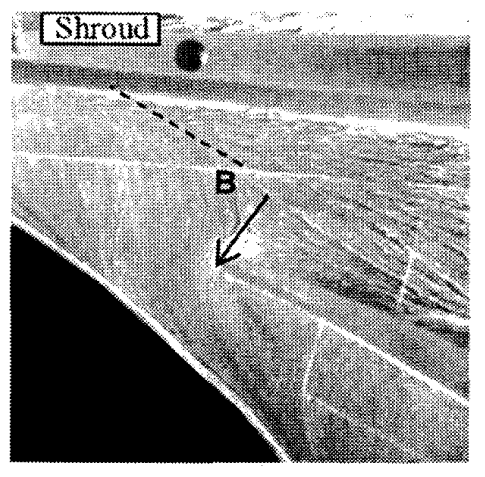

(iii) Shroud wall near leading edge $(\phi=0.18)$

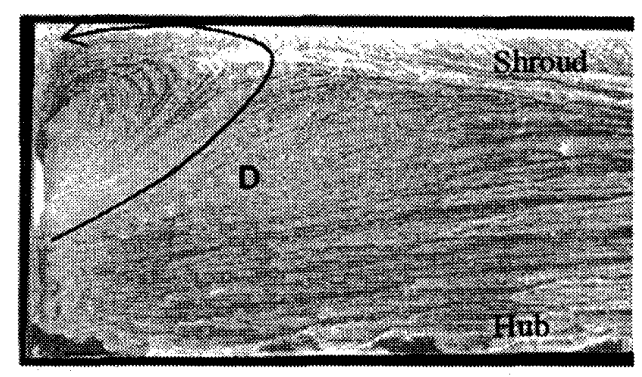

(iv) Suction surface near leading edge $(\phi=0.18)$

Fig. 6 Visualization of diffuser passages and leading-edge vortex (LEV) (Original vane, $\phi=0.24$ and 0.18 ) 
6 から，動静翼間のセミベーンレス部において，逆流 領域が存在することがわかる：図 6(i)，(iii）におけ る案内羽根前縁部の黒色破線(それぞれ，A，B) は逆

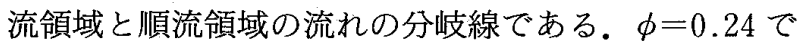
は，案内羽根先端付近に分岐線が存在する[図 6(i) 中の A]. 一方, $\phi=0.18$ では, 分岐線は案内羽根翼 間内部まで後退しており [図 6(iii) 中のB]，シュラウ ド壁面近傍における逆流量領域が拡大している。

図 6(ii ),（iv）に示す案内羽根負圧面の前縁部にお ける油膜法可視化結果により, 案内羽根前縁近傍のシ ユラウド側に渦を形成する流れの軌跡が確認される [図 6(ii) 中の C].この渦が本研究で着目する前縁渦 であり，この前縁渦の挙動については，非定常数值解 析の結果を用いて $5 \cdot 4$ 節にて述べる.

この前縁渦は図 6(iv) 中の D から流量低下と共に大

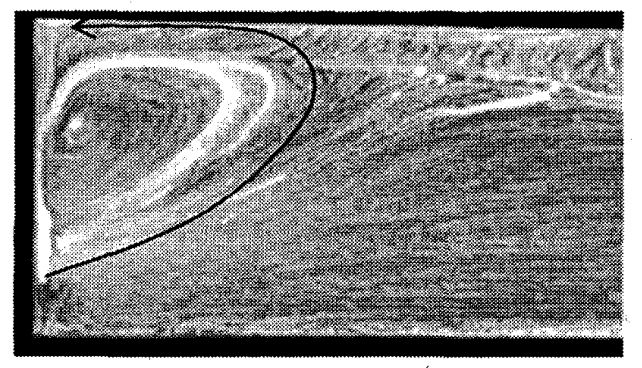

Fig. 7 Flow field visualized by oil-film method (Original vane, $\phi=0.14$ )

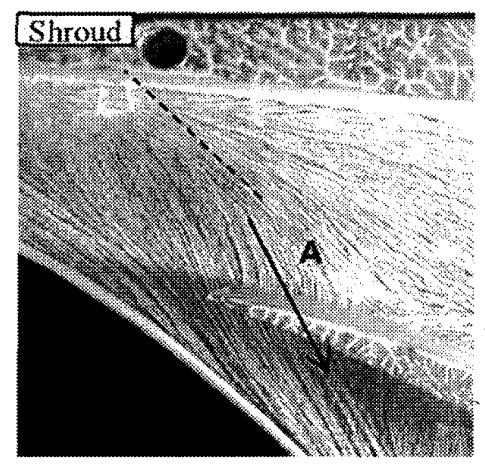

(i) Shroud wall near leading edge $(\phi=0.24)$

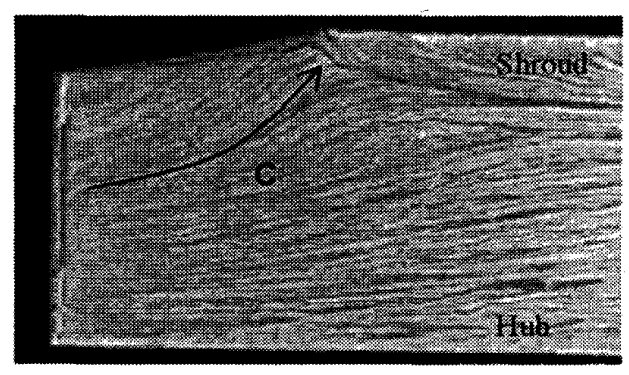

(ii) Suction surface near leading edge ( $\phi=0.24)$
きく成長することがわかる. $\phi=0.18$ では，前縁渦は 通路幅 $B_{4}$ の約 $60 \%$ まで成長している．さらに流量の 低下した $\phi=0.14$ では，図 7 に示すように約 $80 \%$ ま で前縁渦は成長する。この渦の成長がシュラウド側近 傍の逆流領域の拡大に寄与していると考えられる。そ のためこの渦の成長を制御することは，遠心圧縮機の 低流量運転状態における性能の改善のために重要とな る.

$\mathbf{5} \cdot \mathbf{3}$ ディフューザ前縁渦の制御 2 種類のテー パ形案内羽根 (HTV およびSTV)が前縁渦に与える 影響を調べるため, 油膜法を実施した。

$\mathrm{STV}$ 設置時の油膜法の結果を図 8 に示す. STV は前縁渦の発生部位である案内羽根前縁部のシュラウ ド側にテーパ加工が施されている. 油膜法の結果か ら，STVを設置した場合にはシュラウド壁面の逆流 領域は案内羽根内部にまで拡大していることがわか る.これは図 8(i) 中の $\mathrm{A}$ および図 8(iii)中のBの 矢印で示すように逆流額域の流れがテーパ部を貫通す るためである。また, 図 6(ii) 中のCおよび図 6(iv) 中のDに確認されたような前縁渦の端面は, 図 8 から は確認されないが, 図 8(ii) 中のCおよび図 8(iv) 中 のDよりミッドスパンからシュラウド側へ向かう流 れが存在することがわかる．このシュラウド壁面近傍 の逆流と案内羽根負圧面の流れ場は，くさび型案内羽 根設置時(図 6)における前縁渦が形成する流れ場とよ

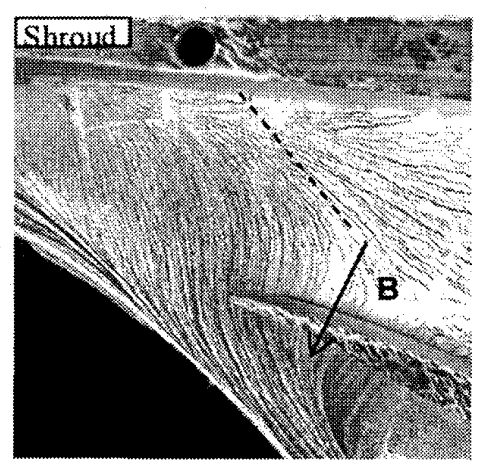

(iii) Shroud wall near leading edge $(\phi=0.18)$

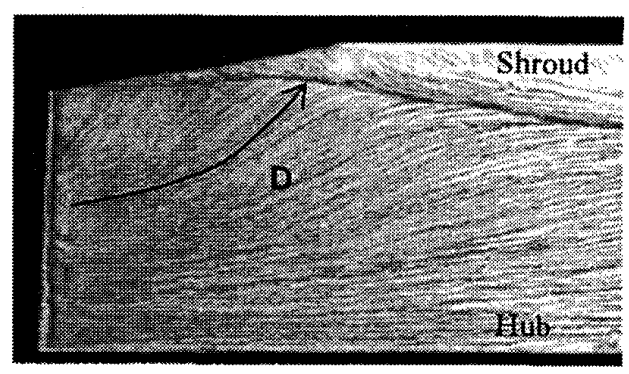

(iv) Suction surface near leading edge ( $\phi=0.18)$

Fig. 8 Visualization of diffuser passages and leading-edge vortex (LEV) (Shroud-side vane, $\phi=0.24$ and 0.18 ) 
く似た傾向を示しており, 前縁渦は依然存在している と考えられる．以上のことから，テーパ部を貫通する 流れによる逆流領域の拡大と前縁渦の存在が, STV 設置時における圧縮機性能劣化の要因である.

次に HTV を設置した場合の可視化結果を図 9 に 示す。前縁渦はHTV 設置時も $\phi=0.24$ において案 内羽根前縁のシュラウド側に存在する[図 9(ii)中の A].また， $\phi=0.24$ では前縁渦の大きさやシュラウ ド壁近傍の流れ(図 9) は図 6 に示したくさび型案内羽 根設置時と非常に酷似している。このことから, 図 4 に示した圧縮機性能はほぼ同等な結果となったと考え られる.一方 $\phi=0.18$ では, 図 6(iv) 中のDに示した くさび型案内羽根設置時の案内羽根負圧面の流れとは 異なり，前縁渦は成長しない [図 $9(\mathrm{iv})$ 中の B].この ため, $\phi=0.18$ においても, 図 6(iii)とは異なり, 逆流 領域は拡大しない [図 9(iii)]. 以上のことから図 4 に示した圧縮機特性において, HTVが低流量運転時 にくさび型案内羽根に比べ高い圧力上昇を維持できる 要因は，HTV を用いることにより前縁渦の成長およ び逆流領域の拡大を抑制できたためである.

5•4 ディフューザ前縁渦の挙動〈さび型案内 羽根と前縁渦の成長を抑制可能であった HTVを対 象として，数值解析を実施した。また，STVは圧縮 機性能が極度に劣化し，その原因は図 8 からテーパ部
を貫通する逆流の増加であることが明らかであり，前 縁渦の成長も抑制できなかったため，数值解析は実施 しなかった. 本数值解析は周期境界下において策施し たものであるが，解析格子(案内羽根 2 翼間)内で完結 する局所的な現象の調查には有効であると考える。な おここからは，特に断りのない限り非定常数値解析で 得た結果について論ずる。

図 10 に $\phi=0.24$ および低流量運転状態 $(\phi=0.20$, 0.16 および 0.14$)$ におけるくさび型案内羽根設置時の 羽根車出口から案内羽根前縁近傍までの周方向空間平 均を施した半径方向速度のスパン方向分布を示す。図 10 の計算面 $(\mathrm{a}) \sim(\mathrm{g})$ 㟍 2 に示す通りである.図 10 からシュラウド側の流速はハブ側の流速に比べ極 端に低速である．また，羽根車出口から案内羽根入口

Table 2 Calculating positions by CFD

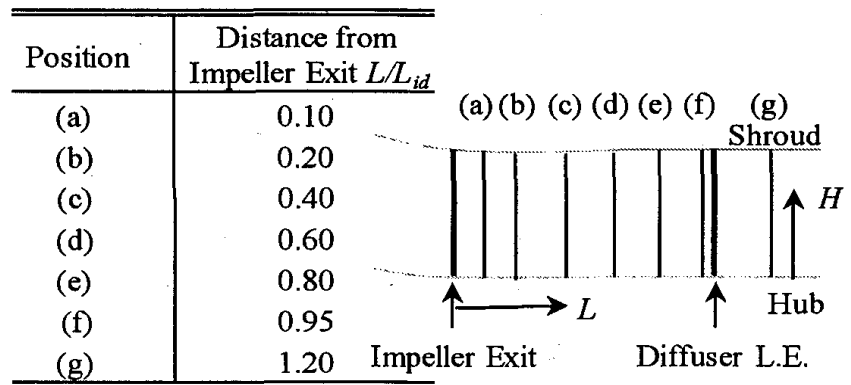

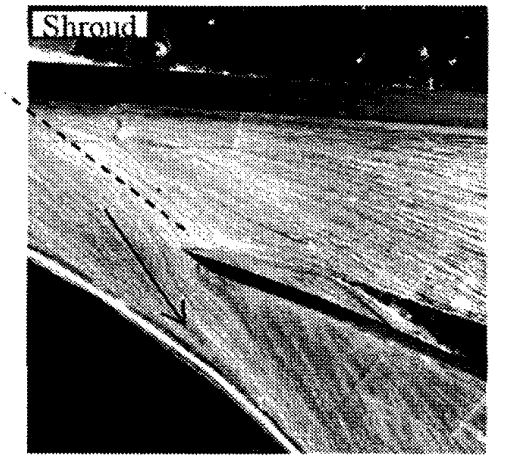

(i) Shroud wall near leading edge $(\phi=0.24)$

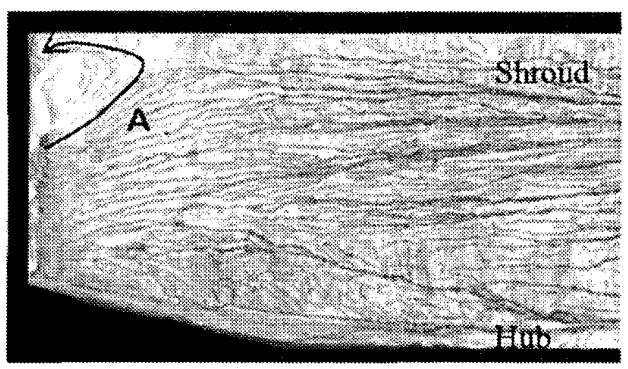

(ii) Suction surface near leading edge $(\phi=0.24)$

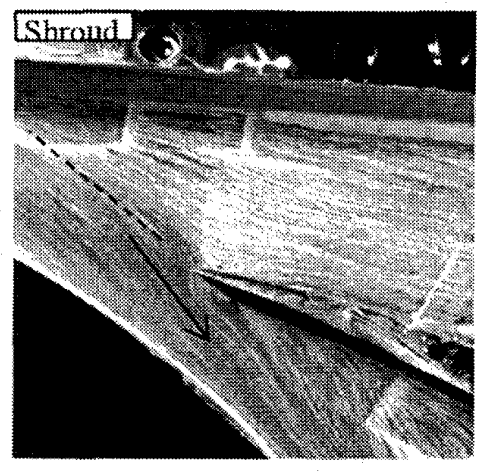

(iii) Shroud wall near leading edge $(\phi=0.18)$

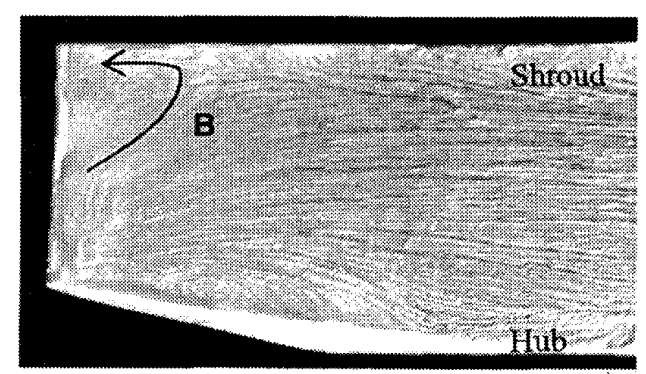

(iv) Suction surface near leading edge $(\phi=0.18)$

Fig. 9 Visualization of diffuser passages and leading-edge vortex (LEV) (Hub-side tapered vane, $\phi=0.24$ and 0.18 ) 


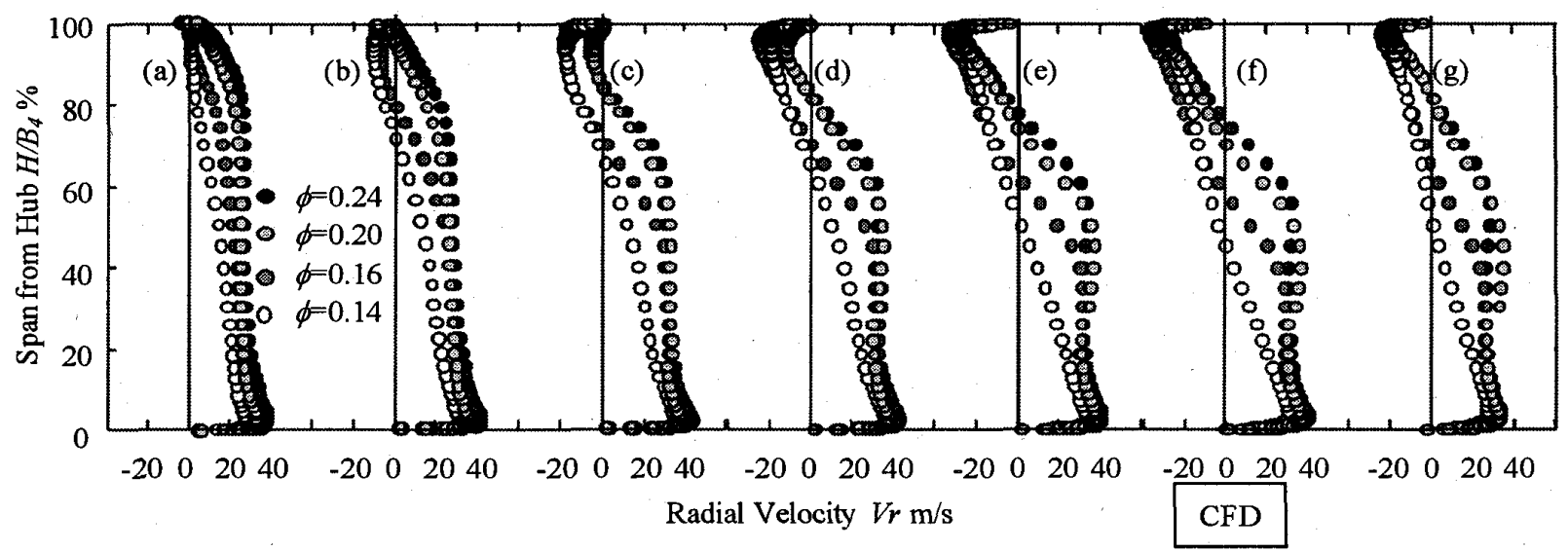

Fig. 10 Distribution of spatial averaged radial velocity

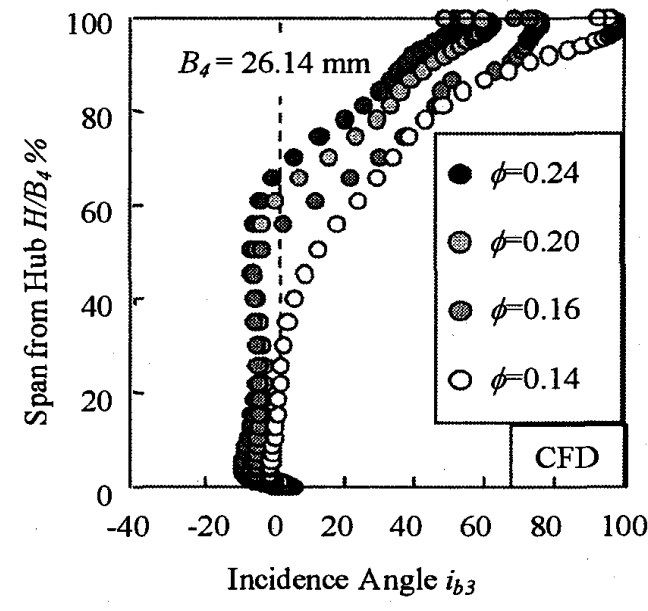

Fig. 11 Incidence angle between hub and shroud side

に近づくにつれ，ディフューザ内の強い逆圧力勾配の 影響を受け，シュラウド側の流れは計算面 (d) 付近か ら空間的に逆流となる。これにより，計算面 (d) 加ら ( g)にかけて, シュラウド側の逆流とミッドスパンの 順流により渦度が定常的に生成され，その蓄積により “前縁渦が形成される．また，案内羽根前縁近傍である ( f ) および $(\mathrm{g})$ では, $\phi=0.24$ および 0.20 の場合, $H$ $=0.6 B_{4}$ 近傍から速度勾配が増大するのに対して, $\phi$ $=0.16$ では $H=0.4 B_{4}$ から， $\phi=0.14$ では， $H=$ $0.1 B_{4}$ 近傍から速度勾配が増大寸る。このことから， $\phi=0.14$ において, 前縁渦はシュラウドからほぼハブ 側まで全スパンにわたって成長すると考えられる。

案内羽根への入射角を図 11 亿示す。谢角 $i_{b 3}$ は, 計測面 (f) における流れ場に対して, 瞬時の流れ角の 周方向平均 $\beta_{3}$ と案内羽根の入口角 $\beta_{b 3}$ を用いて算出 した. $\phi=0.24,0.20$ および 0.16 の場合, 八ブ側から ミッドスパンにかけての入射角 $i_{b 3}$ はほほ $0^{\circ}$ もしくは 負となっている。しかし，シュラウド側に近づくにつ れて急激に正と変化している。図 10 に示した計算面

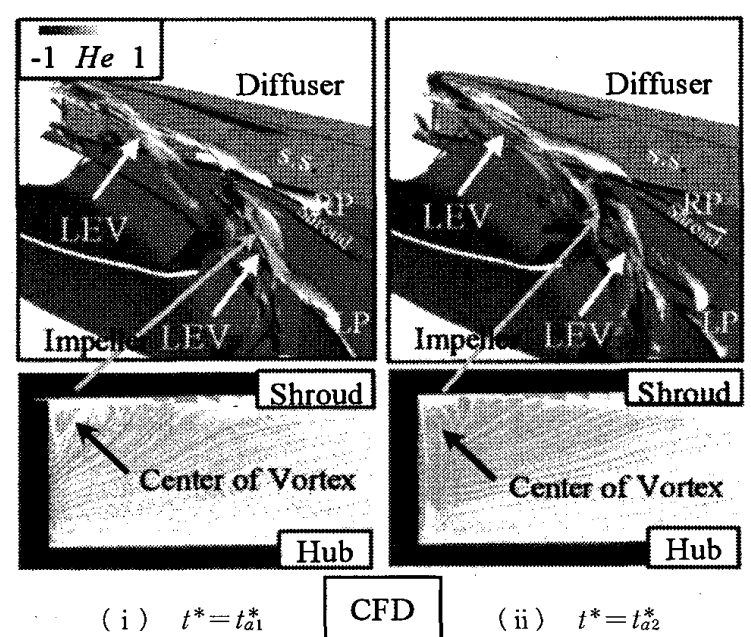

Fig. 12 Behavior of leading-edge vortex (Original vane, $\phi=0.24$ )

(f)における半径方向流速がシュラウド側でハブ側に 比べ低速ないし逆流していること，また入射角 $i_{b 3}$ が ハブ側に比べ正であることから，案内羽根入口近傍で は, 速度三角形は周方向に大きく変形している。この ため，前縁渦は下流側の隣接翼前縁に向かって成長す る.この傾向はくさび型案内羽根設置時における前縁 渦の渦構造を速度勾配テンソルの 2 次不変量の等值面 により抽出し可視化(16) を行った図 12 からも確認でき る.この前縁渦の周方向への成長によって, 前緑渦は 流路ブロッケージを形成し，ディフューザ主流の流れ を阻害し, ディフューザ損失となる。

図 12 はくさび型案内羽根設置時の前縁渦を速度勾 配テンソルの 2 次不変量の等值面より可視化 ${ }^{(16)}$ を行 った結果と，案内羽根負圧面前緑近傍の限界流線を示 している．また洞構造は無次元へリシティ $H e$ より濃 淡表示した。前縁渦は無次元へリシティ $H e$ が約 
0.92 であることから, 縦渦と判断され, 図 10 に示す ような半径流速のスパン方向分布によって生じる強い せん断流によって生成される渦度が案内羽根前縁シュ ラウド側に蓄積されることにより図 12 のように形成 される。一方, 従来から報告されている案内羽根前縁 に生じる剥離渦は, 案内羽根前縁に拈ける流れの剥離 により生成される横渦によって形成される。このこと から, 前縁渦は案内羽根前縁剥離渦や通路渦とは異な った渦であると考えられる。また，図 13 は図 12 中の

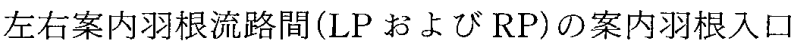
近傍の計測面 $(\mathrm{g})$ を通過する瞬時の流量を断面積で除 し求めた速度を羽根車周速により無次元化した速度で あり，実線は左側流路(LP)，破線は右側流路(RP)に それぞれ対応している。横軸は数值的な圧力および流 量の振動が収束した時刻を基準時刻 $t=0$ として 1 翼 通過時間で無次元化した無次元時間を, 縦軸は羽根車

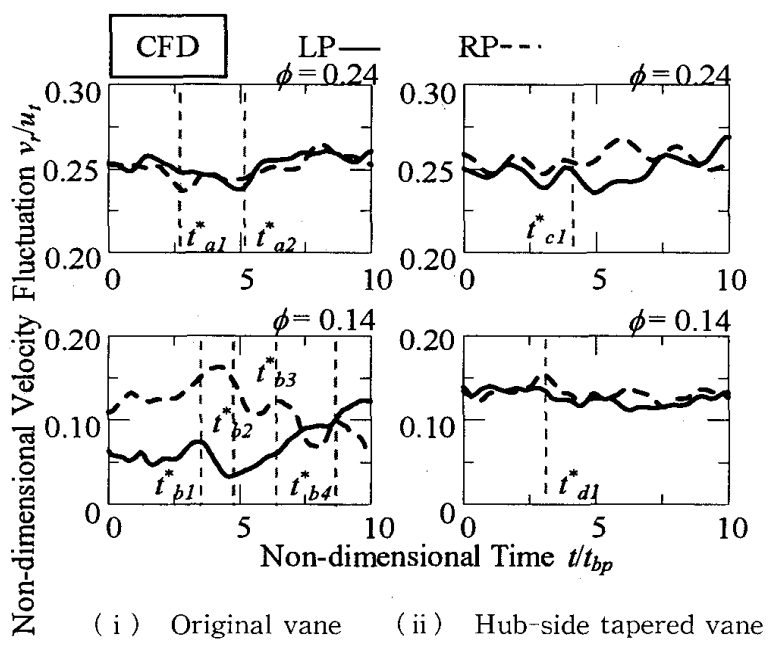

Fig. 13 Velocity fluctuation (Original vane)
出口周速で無次元化した無次元速度変動とした。時刻 は, LP側の速度変動において極値を取る時刻を選定 した．また, 図 12 の無次元時刻 $\left(t_{a 1}^{*}\right.$ および $t_{a 2}^{*}$ ) は図 13 に示す時刻と対応している，図 12 における前縁渦 は案内羽根前縁の負圧面シュラウド側から発生してお り，限界流線の形状と図 6(左下)に示した油膜法によ る可視化結果と非常によく一致している．また，本数 值解析は案内羽根翼枚数を 14 枚に近似しており羽根 車翼枚数と一致していることから, 羽根車吐出流の位 相差は左右翼間において生じないと考えられるが，図 13 からくさび型案内羽根設置における $\phi=0.24$ の速 度変動は左右翼間に扔いてよい一致を示している。

一方, $\phi=0.14$ では, 図 13 から左右翼間の速度変動 は大きく異なっている. 特に LP 側は RP 側に比べ, 非常に低流速となることから, 局所的な案内羽根翼間 失速に宿っていると考えられる。図 14 の前縁渦の可 視化結果から, $t^{*}=t_{b 1}^{*}$ において LP 側の前縁渦は $\phi=$ 0.24 に比べて大きく成長しており，ほぼハブ側まで㹡 大していることがわかる。このことから，前縁渦が大 きく成長することにより, 案内羽根入口の全スパンに わたってブロッケージを形成することが, 案内羽根翼 間に発生する局所的な失速の原因である。また, LP 側の流量が増加するに従い, 前縁渦の大きさは徐々に 縮小しており，さらにRP側の流量が減少することか ら，この前縁渦の時間的な拡大縮小運動が遠心圧縮機 におけるディフューザ部に発生する失速現象の初生の 一要因であると考えられる。

図 15 にTV 設置時に扔ける前縁渦の可視化結果 を示す.図 13 から HTV 設置時においては, $\phi=0.24$ は実験結果と同様，くさび型案内羽根設置時と似た傾 向を示し, 左右翼間の速度変動はよく一致する。また

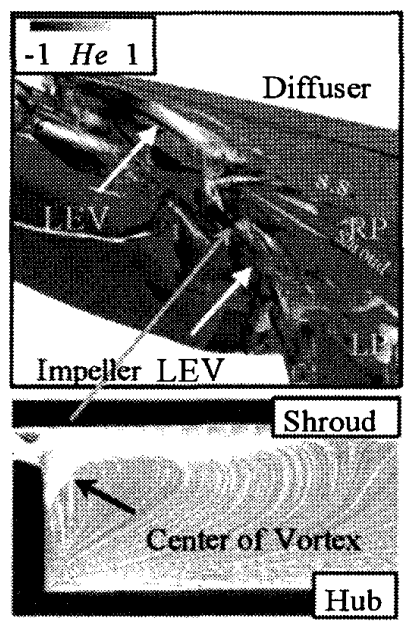

( i ) $t^{*}=t_{b 1}^{*}$

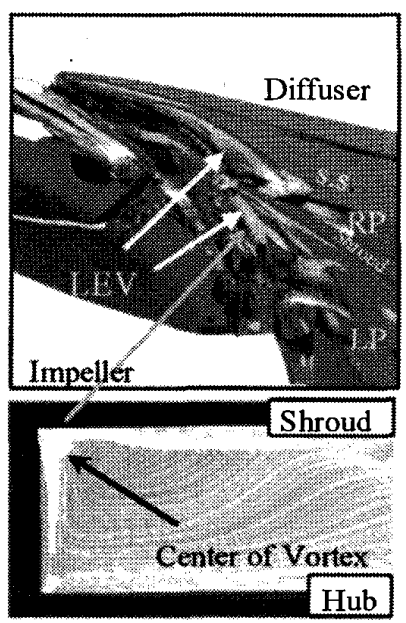

(ii) $t^{*}=t_{b 2}^{*}$

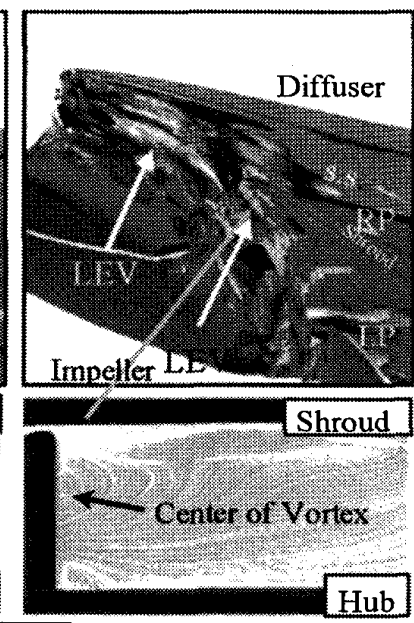

(iii) $t^{*}=t_{b 3}^{*}$

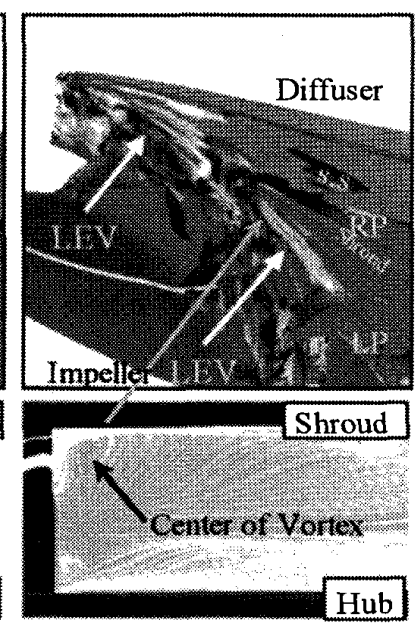

(iv) $t^{*}=t_{b 4}^{*}$

Fig. 14 Unsteady behavior of leading-edge vortex (Original vane, $\phi=0.14$ ) 


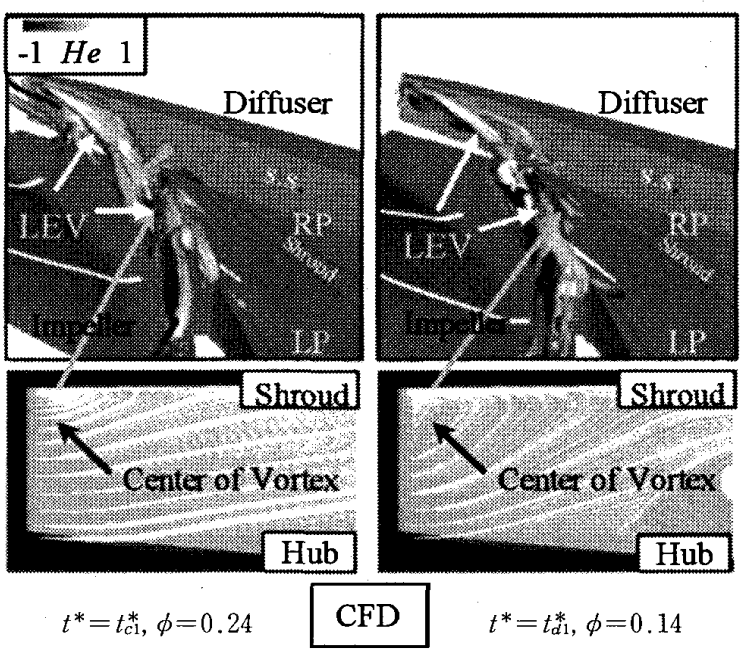

Hub-side Tapered Vane

Fig. 15 Behavior of the leading-edge vortex (LEV)

図 15 より前縁渦は案内羽根前縁のシュラウド側に存 在することが確認される.一方 $\phi=0.14$ においても， 左右翼間の速度変動に大きな差異は表れておらず，案 内羽根翼間に発生する局所的な失速は確認できない. また前縁渦も，流量低下にもかかわらず，大きく成長 しない(図 15)。以上のことから，ハブ側テーパ形案内 羽根を設置することにより，低流量運転状態における 前縁渦の成長を抑制すると共に，ディフューザ部に発 生する失速を回避できると考えられる。

\section{6. 結言}

ディフューザ前縁渦の非定常挙動と, 圧縮機性能お よび発生騒音の関連性を調査するために，実験および 数値解析を実施した。また，2 種類のテーパ形案内羽 根が前縁渦や圧縮機性能に与える影響について調査を 行い, 以下の知見を得た。

（1）ディフューザ前縁渦は案内羽根前縁の負圧面 シュラウド側に広い流量範囲に扔いて存在する。この 前縁渦は剶離渦とは異なり縦渦で構成されており，隣 接翼方向に成長する。

（2）前縁渦は流量低下と共に大きく成長した。く さび型案内羽根設置時には低流量運転状態ではシュラ ウド側からハブ側までほぼ全スパンにわたって成長 し，流路ブロッケージを形成した。このため，ディフ ユーザ部の主流は阻害され，局所的なディフューザ失 速が生じる。

（3）案内羽根前縁のシュラウド側もしくはハブ側 にテーパ加工を施したテーパ形案内羽根を適用した。 シュラウド側テーパ形案内羽根はテーパ部を貫通する 流れが逆流となりディフューザ損失が増大するため,
内部流れ場は改善されず，前縁渦の制御もできない. 一方，八ブ側テーパ形案内羽根は前縁渦の成長を抑制 することが可能である。

（4）テーパ形案内羽根は動静翼干渉騒音だけでな く，広帯域騒音の低減にも効果的である．特にハブ側 テーパ形案内羽根を用いると, 高性能を維持しつつ発 生騒音を低減することが可能である，さらに，低流量 運転時には，圧縮機性能を改善することも可能であ る.

\section{文献}

(1) Yoshinaga, Y., Gyobu, I., Mishina, H., Koseki, F. and Nishida, H., Aerodynamic Performance of a Centrifugal Compressor with Vaned Diffusers, Transaction of the ASME, Journal of Fluids Engineering, Vol. 102 (1980), pp. 486-493.

(2) Kodama, Y., Hayashi, H., Murayama, S., Kondo, S. and Yamaguchi, H., A Study of Discrete Frequency Noise on a Jet Fan, Journal of Turbomachinery Society of Japan, Vol. 29 (2001), pp. 611-618 (in Japanene).

(3) Kobayashi, H., Nishida, I., Miura, H. and Yoshikai, H., Noise in Centrifugal Compressor: 1st Report, Influence of the Diffuser Vane on Noise, Transactions of the Japan Society of Mechanical Engineers, Series B, Vol. 62, No. 598 (1996), pp. 2303-2309.

(4) Nishida, H., Kobayashi, H., Takagi, T. and Fukushima, Y., A Study on the Rotating Stall of Centrifugal Compressors : 1st Report, Effect of Vaneless Diffuser Width on Rotating Stall, Transactions of the Japan Society of Mechanical Engineers, Series B, Vol. 54, No. 499 (1988), pp. 589-594.

(5) Adachi, Y., Bando, K., Miyake, Y. and Otsuki, A., Performance Improvement of a Vaneless Diffuser of Centrifugal Compressor, Transactions of the Japan Society of Mechanical Engineers, Series B, Vol. 58, No. 550 (1992), pp. 1796-1802.

(6) Nakagawa, K., Keimi, Y., Uraki, Y., Terasaki, M. and Sato, T., Comparison of Anti-Stall Effect of Two Diffusers in a Centrifugal Compressor, Transactions of the Japan Society of Mechanical Engineers, Series B, Vol. 67, No. 664 (2001), pp. 2993-2997.

(7) Hayami, H., Senoo, Y., Utsunomiya, K., Hasegawa, H. and Kawaguchi, N., Low-Solidity Cascade Diffuser for Transonic Centrifugal Compressor, Transactions of the Japan Society of Mechanical Engineers, Series B, Vol. 55, No. 511 (1989), pp. 758-763.

(8) Ohta, Y., Outa, E. and Tajima, K., Evaluation and Prediction of Blade-Passing Frequency Noise Generated by a Centrifugal Blower, Transaction of the ASME, Journal of Turbomachinery, Vol. 118 (1996), pp. 597605

(9) Ohta, Y., Takehara, N., Okutsu, Y. and Outa, E., Effects of Diffuser Vane Geometry on Interaction Noise Generated from a Centrifugal Compressor, Jour. nal of Thermal Science, Vol. 14, No. 4 (2005), pp. 321328.

(10) Ohta, Y., Goto, T. and Outa, E., Effects of Tapered Diffuser Vane on the Flow Field and Noise of a Centrifugal Compressor, Journal of Thermal Science, Vol. 16, No. 4 (2007), pp. 301-308. 
(11) Goto, T., Ohta, Y. and Outa, E., Improvement of Aerodynamic Performance and Noise Reduction of Centrifugal Compressor with Tapered Diffuser Vane, Proceedings of the International Gas Turbine Congress 2007, (2007), TS-033 (CD-ROM).

(12) Deng, X.G. and Zhang, H., Developing High-Order Weighted Compact Nonlinear Schemes, Journal of Computational Physics, Vol. 165 (2000), pp. 22-44.

(13) Roe, P. L., Approximate Riemann Solvers, Parameter Vectors, and Difference Schemes, Journal of Computational Physics, Vol. 43 (1981), pp. 357-372.

(14) Yoon, S. and Jameson, A., Lower-Upper Symmetric
Gauss-Seidel Method for the Euler and Navier-Stokes Equations, AIAA Joumal, Vol. 26 (1988), pp. 10251026.

(15) Spalart, P. R., Jou, W. H., Strelets, M. and Allmaras, S. R., Comments on the Feasibility of LES for Wings and on the Hybrid RANS/LES Approach, Proceedings of the First AFOSR International Conference on DNS/ LES, (1997), pp. 137-147.

(16) Jeong, J. and Hussain, F., On the Identification of a Vortex, Journal of Fluid Mechanics, Vol. 285 (1995), pp. 69-94. 